\title{
PERBEDAAN KEBAHAGIAN PADA KELUARGA PRASEJAHTERA DAN SEJAHTERA DI DESA MOPUYA UTARA KECAMATAN DUMOGA UTARA KABUPATEN BOLAANG MONGONDOW
}

\author{
${ }^{1}$ I Wayan A. Kusuma \\ ${ }^{2}$ Cicilia Pali \\ ${ }^{2}$ Lydia David \\ ${ }^{1}$ Kandidat Skripsi Fakultas Kedokteran Universitas Sam Ratulangi Manado \\ ${ }^{2}$ Bagian Psikologi Fakultas Kedokteran Universitas Sam Ratulangi \\ Email:wayanandra@ymail.com
}

\begin{abstract}
Basically, everyone wants to be happy, however, happiness depends on many factors. A prosperous family can fulfil the needs of its members; the needs of food, clothing, housing, social, and religious. Meanwhile, the preprosperous family cannot fulfil its members' minimal basic needs. This study aimed to determine the difference of happiness between prosperous and preprosperous families in North Mopuya village, Dumoga Utara, Bolaang Mongondouw. This was an observational analytical study using a cross-sectional design. Samples were 118 villagers consisted of 59 people of prosperous family group and 59 people of preprosperous group. The results showed a p value of $0.00(<0.05)$. Conclusion: There was a difference in happiness between prosperous and preprosperous families in the North Mopuya village.
\end{abstract}

Keywords: happiness, family, prosperous, preprosperous

\begin{abstract}
Abstrak: Pada dasarnya semua orang ingin bahagia namun kebahagiaan dipengaruhi oleh berbagai macam faktor. Keluarga sejahtera ialah keluarga yang dapat memenuhi kebutuhan anggota baik kebutuhan sandang, pangan, perumahan, sosial, dan agama. Keluarga prasejahtera yaitu keluarga-keluarga yang belum dapat memenuhi kebutuhan dasarnya secara minimal. Penelitian ini bertujuan untuk mengetahui perbedaan kebahagiaan antara keluarga prasejahtera dan sejahtera di Desa Mopuya Utara Kecamatan Dumoga Utara Kabupaten Bolaang Mongondouw. Penelitian ini menggunakan metode analitik observasional dengan desain potong lintang. Sampel penelitian sejumlah 118 orang di desa Mopuya Utara terdiri dari 59 orang dalam kelompok keluarga sejahtera dan 59 orang dalam kelompok keluarga prasejahtera. Hasil uji statistik memperlihatkan $\mathrm{p}=0,00(\mathrm{p}<0,05)$. Simpulan: Terdapat perbedaan kebahagiaan antara keluarga sejahtera dan prasejahtera di desa Mopuya Utara.
\end{abstract}

Kata kunci: kebahagiaan, keluarga, sejahtera, prasejahtera

Kebahagiaan adalah suatu perasaan atau keadaan dimana seseorang merasakan kesenangan, ketentraman hidup, keberuntungan, kemujuran yang semuanya bersifat lahir dan batin. Kebahagiaan dianggap sebagai tujuan akhir dari kehidupan dan pada dasarnya semua orang ingin bahagia. ${ }^{1}$

Faktor lain yang juga memengaruhi kebahagiaan adalah variabel demografis dan lingkungan salah satunya pendapatan, banyak penelitian yang menyebutkan bahwa pendapatan berhubungan dengan kebahagiaan dan juga dapat menjadi tolak ukur kesejahteraan dalam suatu keluarga. ${ }^{2,3}$

Menurut Easterlin hubungan kebahagiaan dengan pendapatan sangat kompleks. Orang dengan pendapatan lebih secara umum lebih bahagia dibandingkan dengan 
mereka yang berkekurangan karena dengan pendapatan yang lebih banyak maka aspirasi kehidupan seseorang akan lebih mudah dicapai. ${ }^{3,4}$

Dalam sebuah studi di Cina, Jepang, dan Korea oleh Oshio ${ }^{4}$ dilaporkan bahwa kebahagiaan seseorang tidak hanya absolut berdasarkan tingkat pendapatan tetapi juga berdasarkan perbandingan tingkat pendapatan dengan sesama khusunya mereka yang memiliki karakteristik sosiekonomik serupa. Hal ini menggambarkan suatu keadaan dimana peningkatan pendapatan orang lain akan menurukan kebahagiaan seseorang walaupun pendapatannya tetap atau bahkan meningkat. ${ }^{4}$

Terdapat beragam pengertian mengenai kesejahteraan, karena lebih bersifat subyektif dimana setiap orang dengan pedoman, tujuan dan cara hidupnya yang berbeda-beda akan memberikan nilainilai yang berbeda pula tentang kesejahteraan dan faktor-faktor yang menentukan tingkat kesejahteraan. Persepsi masyarakat mengenai kesejah-teraan juga berbeda-beda. Oleh sebab itu dibutuhkan penjabaran yang detail dan hati-hati dengan memperhatikan keragaman dan kondisi sosial budaya masyarakat. ${ }^{5}$

Konsep keluarga sejahtera menurut UU No. 10 tahun 1992 adalah keluarga yang dibentuk atas perkawinan yang sah, mampu memenuhi kebutuhan spiritual dan materiil yang layak, bertaqwa kepada Tuhan YME, memiliki hubungan yang serasi, selaras, dan seimbang antar anggota dan antar keluarga dengan masyarakat dan lingkungannya. ${ }^{6,7}$

BKKBN merumuskan pengertian keluarga sejahtera sebagai keluarga yang dapat memenuhi kebutuhan anggota baik kebutuhan sandang, pangan, perumahan, sosial dan agama. Sedangkan keluarga prasejahtera yaitu keluarga-keluarga yang belum dapat memenuhi kebutuhan dasarnya (basic needs) secara minimal, seperti kebutuhan akan pangan, sandang, papan, kesehatan dan pendidikan. ${ }^{6}$

\section{METODE PENELITIAN}

Penelitian ini menggunakan metode analitik observasional dengan rancangan potong lintang. Penelitian ini dilakukan di Desa Mopuya Utara Kecamatan Dumoga Utara Kabupaten Bolmong tahun 2013. Data diambil dengan menggunakan kuisioner skala kebahagiaan Seligman. Cara pengisian kuisioner ialah dengan memberikan skor 29 butir pertanyaan yang ditanyakan kemudian data dianalisis dengan program SPSS v20.0

\section{HASIL PENELITIAN}

Sampel penelitian sebesar 118 orang yang dibagi menjadi 2 kelompok yaitu 59 orang kelompok keluarga prasejahtera dan 59 orang kelompok keluarga sejahtera. Tabel 1 memperlihatkan jumlah laki-laki pada keluarga prasejahtera 53 orang (89,8\%) dan pada keluarga sejahtera sebanyak 31 orang (52,5\%) sedangkan jumlah wanita pada keluarga prasejahtera 6 orang $(10,2 \%)$ dan pada keluarga sejahtera 28 orang $(47,5 \%)$.

Tabel 1. Distribusi Status Keluarga berdasarkan Jenis Kelamin

\begin{tabular}{ccccc}
\hline \multirow{2}{*}{ Jenis Kelamin } & \multicolumn{2}{c}{ Prasejahtera } & \multicolumn{2}{c}{ Sejahtera } \\
\cline { 2 - 5 } & Frekuensi & $\%$ & Frekuensi & $\%$ \\
\hline Laki-laki & 53 & 89,8 & 31 & 52,5 \\
Perempuan & 6 & 10,2 & 28 & 47,5 \\
Total & 59 & 100,0 & 59 & 100,0 \\
\hline
\end{tabular}

Tabel 2 memperlihatkan distribusi berdasarkan kelompok umur. Pada kedua kelompok keluarga, kelompok umur terbanyak ialah 36-45 tahun yaitu 49,2\% pada keluarga prasejahtera dan 37,3\% pada keluarga sejahtera. 
Tabel 2. Distribusi Status Keluarga Berdasarkan Kelompok Umur

\begin{tabular}{ccccc}
\hline \multirow{2}{*}{$\begin{array}{c}\text { Kelompok Umur } \\
\text { (tahun) }\end{array}$} & \multicolumn{2}{c}{ Prasejahtera } & \multicolumn{2}{c}{ Sejahtera } \\
\cline { 2 - 5 } & Frekuensi & $\%$ & Frekuensi & $\%$ \\
\hline $18-25$ & 5 & 8,5 & 7 & 11,9 \\
$26-35$ & 12 & 20,3 & 20 & 33,9 \\
$36-45$ & 29 & 49,2 & 22 & 37,3 \\
$46-55$ & 7 & 11,9 & 5 & 8,5 \\
$56-65$ & 2 & 3,4 & 4 & 6,8 \\
$>66$ & 4 & 6,8 & 1 & 1,7 \\
Total & 59 & 100,0 & 59 & 100,0 \\
\hline
\end{tabular}

Tabel 3 memperlihatkan distribusi berdasarkan tingkat pendidikan. Pada kedua kelompok keluarga, pendidikan terbanyak ialah SD yaitu $81,4 \%$ pada keluarga prasejahtera dan 57,6\% pada keluarga sejahtera.

Tabel 3. Distribusi Status Keluarga berdasarkan Tingkat Pendidikan

\begin{tabular}{ccccc}
\hline \multirow{2}{*}{ Pendidikan } & \multicolumn{2}{c}{ Prasejahtera } & \multicolumn{2}{c}{ Sejahtera } \\
\cline { 2 - 5 } & Frekuensi & $\%$ & Frekuensi & $\%$ \\
\hline Tidak tamat SD & 8 & 13,6 & 0 & 1,3 \\
SD & 48 & 81,4 & 34 & 57,6 \\
SMP & 2 & 3,4 & 12 & 20,3 \\
SMA & 1 & 1,7 & 8 & 13,6 \\
Diploma & 0 & 0,0 & 2 & 3,4 \\
Sarjana & 0 & 0,0 & 3 & 5,1 \\
Total & 59 & 100,0 & 59 & 100,0 \\
\hline
\end{tabular}

Tabel 4 memperlihatkan distribusi berdasarkan skala kebahagiaan, yaitu nilai yang didapat saat mengisi kuesioner dan diinterpretasikan hasilnya. Pada kedua kelompok keluarga, skala kebahagiaan terbanyak ialah 'kurang bahagia' yaitu 91,5\% pada keluarga prasejahtera dan $71,2 \%$ pada keluarga sejahtera. Skala kebahagiaan 'bahagia' hanya ditemukan pada keluarga sejahtera sebanyak 22\%.

Tabel 4. Distribusi Status Keluarga Berdasarkan Skala Kebahagiaan

\begin{tabular}{ccccc}
\hline \multirow{2}{*}{ Skala Kebahagiaan } & \multicolumn{2}{c}{ Prasejahtera } & \multicolumn{2}{c}{ Sejahtera } \\
\cline { 2 - 5 } & Frekuensi & $\%$ & Frekuensi & $\%$ \\
\hline Sangat tidak bahagia & 0 & 0,0 & 0 & 0,0 \\
Tidak bahagia & 5 & 8,5 & 1 & 1,7 \\
Kurang bahagia & 54 & 91,5 & 42 & 71,2 \\
Cukup bahagia & 0 & 0,0 & 3 & 5,1 \\
Bahagia & 0 & 0,0 & 13 & 22,0 \\
Sangat bahagia & 0 & 0,0 & 0 & 0,0 \\
Total & 59 & 100,0 & 59 & 100,0 \\
\hline
\end{tabular}

Tabel 5 memperlihatkan hasil uji statistik Independent-Samples $T$ test untuk mengukur apakah terdapat perbedaan kebahagiaan pada keluarga prasejahtera 
dan sejahtera. Hipotesis pada penelitian ini yaitu H0 (mean status kebahagiaan keluarga prasejahtera sama dengan keluarga sejahtera) dan $\mathrm{H} 1$ (mean status kebahagiaan keluarga prasejahtera tidak sama dengan keluarga sejahtera). Hasil dari Sig. (tailed) atau diketahui sama dengan $\mathrm{P}$ adalah 0,000 dimana nilai $\mathrm{P}<0,05$ yang menyimpulkan bahwa $\mathrm{H} 1$ diterima berarti status kebahagiaan keluarga prasejahtera tidak sama dengan keluarga sejahtera dimana keluarga sejahtera lebih bahagia dibandingkan keluarga prasejahtera.

Tabel 5. Uji T Independent Perbedaan Status Keluarga

\begin{tabular}{|c|c|c|c|c|c|c|}
\hline & & $\mathrm{F}$ & Sig. & $\mathrm{T}$ & $\mathrm{df}$ & $\begin{array}{l}\text { Sig. (2- } \\
\text { tailed) }\end{array}$ \\
\hline \multirow{2}{*}{$\begin{array}{c}\text { Skala } \\
\text { Kebahagiaan }\end{array}$} & \multirow{2}{*}{$\begin{array}{c}\text { Equal variances assumed } \\
\text { Equal variances not } \\
\text { assumed }\end{array}$} & \multirow[t]{2}{*}{557,516} & \multirow[t]{2}{*}{,000 } & $-7,964$ & 376 & .000 \\
\hline & & & & $-15,945$ & 341,429 & .000 \\
\hline
\end{tabular}

\section{BAHASAN}

Kebahagiaan hidup adalah suatu hal yang menjadi harapan dalam kehidupan banyak orang, bahkan sepertinya semua orang mendambakan kehidupan yang berbahagia. Berbagai penelitian mengenai kebahagiaan mengaitkan kebahagiaan sebagai bagian dari kesejahteraan subyektif, disamping variabel kepuasan hidup dan rendahnya suasana hati negatif atau rendahnya neurotisisme. ${ }^{8}$

Tujuan hidup manusia ialah kebahagiaan. Orang yang sudah bahagia tidak memerlukan apa-apa lagi pada satu sisi, dan pada sisi lain tidak masuk akal jika ia masih ingin mencari sesuatu yang lain. Hidup manusia akan semakin bermutu manakala semakin dapat mencapai apa yang menjadi tujuan hidupnya. Dengan mencapai tujuan hidup, manusia akan mencapai dirinya secara penuh, sehingga mencapai mutu yang terbuka bagi dirinya.

Pada Tabel 1 dapat dilihat bahwa jumlah laki-laki pada keluarga prasejahtera dan sejahtera adalah 53 orang $(89,8 \%)$ dan 31 orang $(52,5 \%)$. Jumlah wanita pada keluarga prasejahtera dan sejahtera adalah 6 orang $(10,2 \%)$ dan 28 orang $(47,5 \%)$. Dari hasil ini diketahui bahwa jumlah lakilaki lebih banyak daripada perempuan Hal ini sesuai dengan data direktorat jenderal kependudukan dan pencatatan sipil pada Kecamatan Dumoga Utara dimana jumlah laki-laki lebih banyak dari perempuan.
Jumlah penduduk laki-laki per tahun 2013 11,828 jiwa dan jumlah perempuan 10,796 jiwa.

Tabel 2 menunjukkan distribusi sampel berdasarkan kelompok umur. Pada kedua kelompok keluarga, kelompok umur terbanyak ialah 36-45 tahun yaitu 49,2\% pada keluarga prasejahtera dan 37,3\% pada keluarga sejahtera. Usia seseorang juga menentukan kebahagiaan dimana usia 3645 tahun yang terbanyak pada kedua keluarga merupakan usia yang krusial dalam membangun kesejahteraan keluarga. $^{2}$

Dari Tabel 3 didapatkan informasi berupa distribusi berdasarkan tingkat pendidikan. Hasil yang ditunjukkan cukup jelas dimana tingkat pendidikan keluarga sejahtera lebih tinggi dibandingkan keluarga prasejahtera. Tingkat pendidikan yang lebih tinggi dapat berdampak pada pekerjaan yang lebih baik dengan penghasilan lebih tinggi yang akan memengaruhi tingkat kebahagiaan seseorang. ${ }^{4,5}$

Tabel 4 memperlihatkan bahwa terdapat perbedaan kebahagiaan menurut skala kebahagiaan Seligman. Pada keluarga prasejahtera didominasi oleh kurang bahagia 91,5\% dan sisanya yang tidak bahagia. Pada keluarga sejahtera walaupun masih didominasi oleh kurang bahagia sebesar 71,2\%, hal ini mungkin disebabkan masih kurang puasnya dengan pencapaian 
yang sudah ada dan masih meninginkan lebih tetapi pada keluarga sejahtera ditemukan juga skala cukup bahagia sebesar 5,1\% dan bahagia sebesar 22\%. Hal ini memperlihatkan suatu perbedaan tingkat kebahagiaan di antara keluarga prasejahtera dan sejahtera.

Secara statistik dibuktikan bahwa terdapat perbedaan kebahagiaan yaitu hasil uji t dengan nilai $\mathrm{P} 0,000$. Nilai $\mathrm{P}<0,05$ berarti status kebahagiaan keluarga prasejahtera tidak sama dengan keluarga sejahtera dimana keluarga sejahtera lebih bahagia dibandingkan keluarga prasejahtera (Tabel 5).

\section{SIMPULAN}

Berdasarkan hasil penelitian yang dilakukan di Desa Mopuya Utara dapat disimpulkan bahwa terdapat perbedaan kebahagiaan antara keluarga prasejahtera dan sejahtera dimana keluarga sejahtera lebih bahagia dibandingkan prasejahtera.

\section{DAFTAR PUSTAKA}

1. Depdiknas. Kamus Besar Bahasa Indonesia (Edisi ketiga). Jakarta: Balai Pustaka,
2010.

2. Eddington N, Shuman R. Subjective Wellbeing (Happiness). Continuing Psychology Education, 2005.

3. Stevenson B, Wolfers J. Happiness Inequality in the United States. Journal of Legal Studies. 2008;37(2):33-79.

4. Easterlin RA. Income and Happiness: Towards A Unified Theory. The Economic Journal. 2001;111:465-84.

5. Oshio T, Nozaki K, Kobayashi M. Relative Income and Happiness in Asia: Evidence from Nationwide Surveys in China, Japan, and Korea. Social Indicator Research. 2011;104:351-67.

6. Sunarti E. Indikator Keluarga Sejahtera: Sejarah Pengembangan, Evaluasi, dan Keberlanjutannya Bogor: IPB, 2006.

7. Presiden Republik Indonesia. Perkembangan Kependudukan dan Pembangungan Keluarga Sejahtera. Undang-Undang No.10. Jakarta, 1992.

8. Leubomirsky S, King L, Diener. The Benefits of Frequent Positive Affect: Does Happiness Lead to Success? University of California, Riverside University of Missouri-Columbia. 2005;131(6):803-55. 